\title{
Exploring Opportunities for Malting Barley Production in Florida ${ }^{1}$
}

\author{
Charles E. Barrett, Lincoln Zotarelli, Sylvia M. Willis, Jay M. Capasso, Ethan T. Carter, De \\ Broughton, Kevin R. Athearn, Andrew Maclntosh, Alicia N. Halbritter, Matthew T. Smith, Kevin
} A. Korus, and Daniel J. Leonard ${ }^{2}$

The craft brewing industry in Florida continues to expand, with more than 426 breweries across the state licensed in the state (Brewer and Long 2021). The impact of these breweries on the state economy is greater than $\$ 3$ billion (Brewers Association 2019). The Florida market is estimated to be large enough to support as many as $500 \mathrm{craft}$ breweries (Taylor et al. 2014). Beer has four ingredients: water, barley (Hordeum vulgare L.), hops, and yeast. Except for water, these ingredients are imported from other states. Demand for craft and boutique fermentation products is growing rapidly and is increasing the demand for local products. The rapid growth of this sector has resulted in many small businesses looking for methods to promote their product, such as the use of local ingredients. Locally grown ingredients will allow diversification of products and support local agriculture and fermentation sectors. Opportunities exist for agritourism and partnerships with craft breweries. With the expansion of the industry, this is an optimal time to establish partnerships between agriculture and fermentation industries to promote locally sourced and novel products. UF/IFAS is researching varieties and cultural practice options adapted for locally grown malting barley and hops. High-quality barley can be produced in north Florida and fits into current crop rotation schemes. This publication aims to inform Florida growers and the craft brewing and distillery industry about the current knowledge of the potential yield and challenges of barley cultivation in north Florida.

\section{Can barley be produced in north Florida?}

North Florida producers are looking for alternative crops because commodity crop prices are depressed, and input costs remain high. Adding complexity to this issue are the pressures producers face to reduce irrigation water consumption and increase nutrient use efficiency, which can require costly equipment upgrades. Malting barley could be an ideal alternative crop because it is potentially profitable, easily incorporated into the current crop rotation, and produced using equipment that is already owned. Environmentally, barley is produced during the winter when the demand for water is lower than for spring crops. Thus, barley uses less water and nutrients than the major agronomic crops grown in the region.

1. This publication is HS1420, one of a series of the Horticultural Sciences Department, UF/IFAS Extension. Original publication date September 2021. Visit the EDIS website at https://edis.ifas.ufl.edu for the currently supported version of this publication.

2. Charles E. Barrett, affiliate professor, Horticultural Sciences Department, and regional specialized agent, water resources; Lincoln Zotarelli, associate professor, Horticultural Sciences Department; Sylvia M. Willis, Extension agent, UF/IFAS Extension Suwannee County; Jay M. Capasso, Extension agent, UF/IFAS Extension Columbia County; Ethan T. Carter, regional crop IPM agent, UF/IFAS Extension Jackson County; De Broughton, regional specialized agent, agronomic crops; Kevin R. Athearn, regional specialized agent, rural and agribusiness development, UF/IFAS North Florida Research and Education Center-Suwanee Valley; Andrew McIntosh, assistant professor, Food Science and Human Nutrition Department; Alicia N. Halbritter, Extension agent, UF/IFAS Extension Baker County; Matthew T. Smith, multicounty Extension agent; Kevin A. Korus, Extension agent, UF/IFAS Extension Alachua County; and Daniel J. Leonard, county Extension director, UF/IFAS Extension Calhoun County; UF/IFAS Extension, Gainesville, FL 32611.

The Institute of Food and Agricultural Sciences (IFAS) is an Equal Opportunity Institution authorized to provide research, educational information and other services

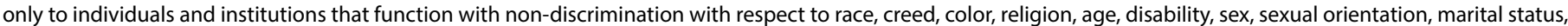

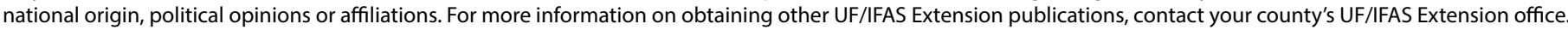
U.S. Department of Agriculture, UF/IFAS Extension Service, University of Florida, IFAS, Florida A \& M University Cooperative Extension Program, and Boards of County Commissioners Cooperating. Nick T. Place, dean for UF/IFAS Extension. 
Most producers interested in producing barley already have the infrastructure in place to easily transition. For example, operations producing grain corn and various small grains are already equipped with the proper planting, harvesting, drying, and storage equipment needed for barley production. Cultural practices and other crop management aspects would also be very similar for barley when compared to other common grains or cover crops grown in north Florida. Another particular advantage of barley is that it fits into a winter growing season, when the potential for producing other cash crops is low, and may provide growers with an opportunity to earn revenue during an otherwise fallow time of year. To assess the potential profitability of any emerging crop, one needs to collect information on region-specific yield, production costs, demand, and market prices.

\section{Current Indications of Demand, Production Feasibility, and Profitability of Florida Barley}

Some indication that malting barley could be a profitable option for the region can be seen by the fast expansion of craft breweries in Florida over the last 10 years. The demand for specialty malts, locally produced malts, and other niche malts has increased with the growth of craft brewing nationwide. A current challenge for the Florida malt market is the difficulty in assessing the profitability because of the distances between production fields and the closest malthouse. The lack of local malthouses may be a barrier for the expansion of the production of barley in Florida. For example, after harvesting barley, it would be necessary to haul the product to a malthouse out of state and, after malting, haul it back to sell in local markets. Another question is whether the malt would qualify for a "Fresh From Florida" label if it was malted out of state. Finally, a stumbling block to evaluating malting barley as a potential alternative crop for Florida is the lack of federal and state funds for such research. Barley is a commodity crop, and as such, it does not fall under consideration for specialty crop funding. With few funding options available, it has been challenging to acquire enough preliminary data to entice private or public funders to invest in malting-barley research.

To begin to address this information gap, a small, "proofof-concept" barley variety trial was conducted in winter 2017-2018 with 10 varieties and two planting dates. The results of the initial trial were very encouraging: 6 of the 10 barley varieties produced marketable yields on the range of 11 to $69 \mathrm{bu} / \mathrm{ac}$, and 3 varieties produced yields comparable with large barley-producing regions of the United States.
The initial trial highlighted the need for more work to be done to optimize Florida malting-barley production. In 2019-2020, a replicated malting-barley trial was conducted with 12 varieties at the urging of many Florida breweries. Details about the 2019-2020 winter barley variety trial evaluation are presented below.

\section{Procedures for Identification of Promising Barley Varieties for Florida}

A field trial was conducted during the 2019-2020 growing season at the UF/IFAS North Florida Research and Education Center-Suwannee Valley in Live Oak, FL. Eleven barley varieties were tested in the trial; however, 'Conlon' was entered from two seed sources (Johnny's Selected Seeds and Albert Lea) for a total of 60 plots (12 varietal entries $\times$ 5 replications) (Table 1 ). The seeds were planted in 50 -footlong plots consisting of 5 rows, using a cone planter. All plots were planted at a rate of $110 \mathrm{lb}$ of seed/acre on 25 November 2019. Fungicide (Proline', Bayer CropScience LP, Durham, NC) was applied 29 January 2020, after net blotch (Pyrenophora teres) and loose smut (Ustilago nuda) were identified in the field. Fertilizer was applied on 22 November 2020, just prior to planting, at a rate of $250 \mathrm{lb} / \mathrm{acre}$, using 14-3-11 N-P-K fertilizer blend. Further applications of fertilizer on 21 January 2020 of 12-4-14 at $400 \mathrm{lb} / \mathrm{acre}$ and 7 February 2020 of 14-4-14 at $230 \mathrm{lb}$ /acre brought the total target $\mathrm{N}$ application to1 $15 \mathrm{lb} /$ acre. Sprinkler irrigation was managed to supplement rainfall and to prevent crop water stress.

The "Suggested Operating Procedures for Collecting Data for the Uniform Eastern Spring Malting Barley Nursery" provided by Dr. Richard Horsley at North Dakota State University were followed for heading date, plant height, stem breakage, and foliar disease resistance. Disease resistance was measured on 27 January 2020. Plant height was measured after all varieties had headed out on 27 February 2020. Stem breakage was measured on 3 April 2020. Harvest was completed on 4 April 2020 and was estimated using the USDA-NASS "Estimating Small Grain Yields" procedure, where:

grain yield $($ bu/acre $)=\left(\right.$ kernels per spike ${ }^{*}$ spikes per 3 feet of row) ${ }^{*} 0.0389$

For the yield estimation, the number of seeds in five representative heads were counted, and all heads collected from 3 feet of row were counted. The seed and head number data were analyzed independently and then entered into 
the equation above for the yield estimate. Statistical analysis was conducted using the Generalized Linear Mixed Model of SAS (SAS Version 9.4; SAS Inst. Inc., Cary, NC). Means separation was completed using a one-way ANOVA with Tukey's HSD test $(\mathrm{P} \leq 0.05)$ to compare differences between varieties.

\section{Top-Performing Barley Varieties and Crop Characteristics}

Plant physiological and yield indicators were collected from the barley varieties during the season. Heading date is an indicator of earliness associated with environmental adaptation and potential yield. Plant height, stem breakage at maturity, and susceptibility to diseases are also indicators of the environmental adaptation of the variety to local soil characteristics and weather conditions, as well as mechanical harvest. Evaluation of total yield and marketable yield are determinant factors for future adoption of the variety by growers.

\section{Heading Date}

The variety Robust was the first to head, on 10 February 2020,78 days after planting. The last variety to head was Genie, on 29 February 2020, 97 days after planting (Table1). Odyssey, Opera, Esma, and Tinka headed within three days of Genie, and all the varieties headed during the last 19 days of February. The number of culled heads that were damaged by frostwas likely linked to heading date and timing of flowering. A challenge to producing spring barley during the winter in north Florida is the timing of frosts during critical periods of grain development. North Florida can experience below-freezing air temperatures at any time during the months of November through April. Barley is most susceptible to frost damage between the boot and flowering stages. Barley is susceptible to frost injury during the boot stage because it begins flowering in the boot. In the boot, the immature grain head is within the leaf sheath. In Florida, boot and flowering coincides with the months of January and February when the crop is planted in November. January and February have a high likelihood of frost occurring, and seed maturation might be hindered during this time. The 19-day difference in heading date between Robust and Genie shows there is potential to select varieties with differing heading dates and time to maturity. A strategy for profitable barley production will likely include staggered planting dates and using varieties that mature at different rates to minimize frost damage.

\section{Plant Height, Stem Breakage at Maturity, and Disease Resistance}

There was a broad range in plant heights, with Robust reaching 47 inches and Genie reaching 13.5 inches (Table 2). Most barley varieties were between 20 and 30 inches in height. All varieties reached an acceptable height to be harvested with a combine.

Stem breakage (lodging) occurred on 31 March 2020, after the barley had reached physiological maturity and was drying in the field (Figure 1). On this date, a cold front passed through the state, bringing wind gusts of over 60 $\mathrm{mph}$. This storm caused some varieties to lodge more than others (Table 2), but all varieties could have been swathed and harvested. Stem breakage did not appear to be related to plant height, disease resistance, or yield. Conlon from both seed sources and Opera were most susceptible to stem breakage, compared to the other varieties.

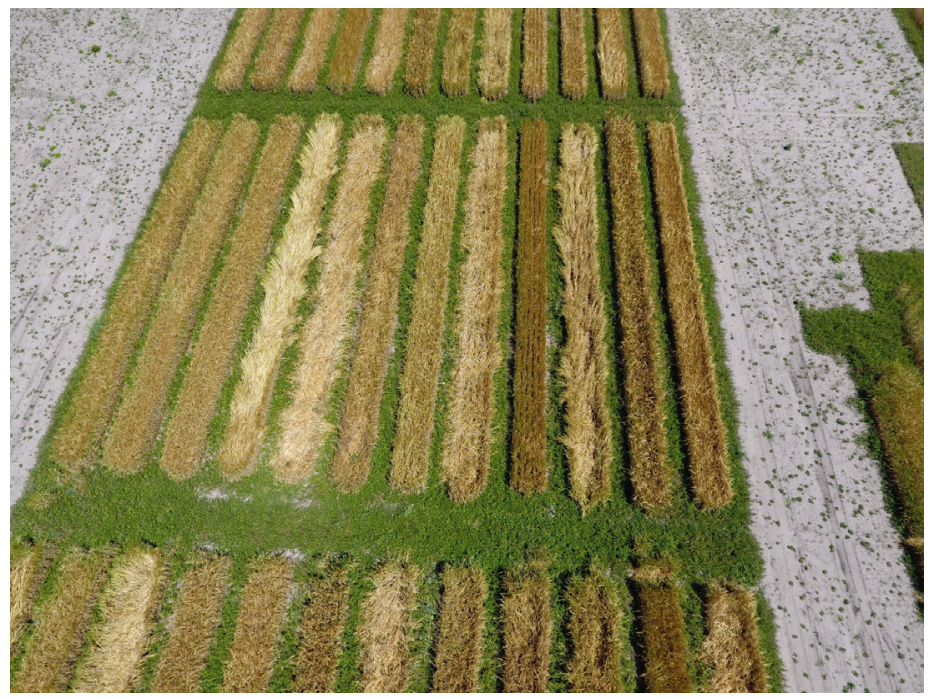

Figure 1. Aerial view of mature barley plots with stem breakage present after 60+ mph wind gusts on 31 March 2020, Live Oak, FL. Credits: Charles Barrett, UF/IFAS

Foliar disease incidence was low as a result of a relatively dry winter and an early application of fungicide at the detection of net blotch on the variety Pinnacle. In a previous trial, Pinnacle was observed to exhibit net blotch symptoms prior to other varieties and was therefore observed in this trial as a sentinel variety to determine when to make a fungicide application. In general, disease ratings were kept low in all varieties by using net blotch symptoms in Pinnacle as a trigger to apply fungicides. Pinnacle had significantly more foliar disease than all other varieties except Esma. 


\section{Yield}

There were significant differences in the number of heads in 3 linear feet of one barley row (Table 3). Robust, the six-row variety, produced fewer heads than Conlon, Genie, Odyssey, Explorer, and Esma. Robust had significantly more seeds per head than any other cultivar, with a mean of 47 seeds per head, while most seed heads from other varieties contained between 20 and 30 seeds per head. Overall, yield was variable, which led to no significant differences between varieties. Some of this yield variability can be explained by frost damage and previous crop history. There were two multinight cold events. Minimum air temperatures were $38.0^{\circ} \mathrm{F}, 31.8^{\circ} \mathrm{F}$, and $37.6^{\circ} \mathrm{F}$ from $21-23$ February 2020 , and $32.4^{\circ} \mathrm{F}, 38.6^{\circ} \mathrm{F}$, and $32.2^{\circ} \mathrm{F}$ from $28-29$ February to 1 March 2020, during which time many varieties were between boot and head emergence stages (Figure 2). There were many frost-damaged heads (Figures 3 and 4) in every plot, which were counted as culls and reported as a percentage of the total number of heads (Table 3 ). These frost-damaged heads were a significant portion of the total number of heads for many varieties and could represent a considerable increase in yield if this potential was met by either varying the planting date to reduce frost damage risk or planting varieties with better frost tolerance.

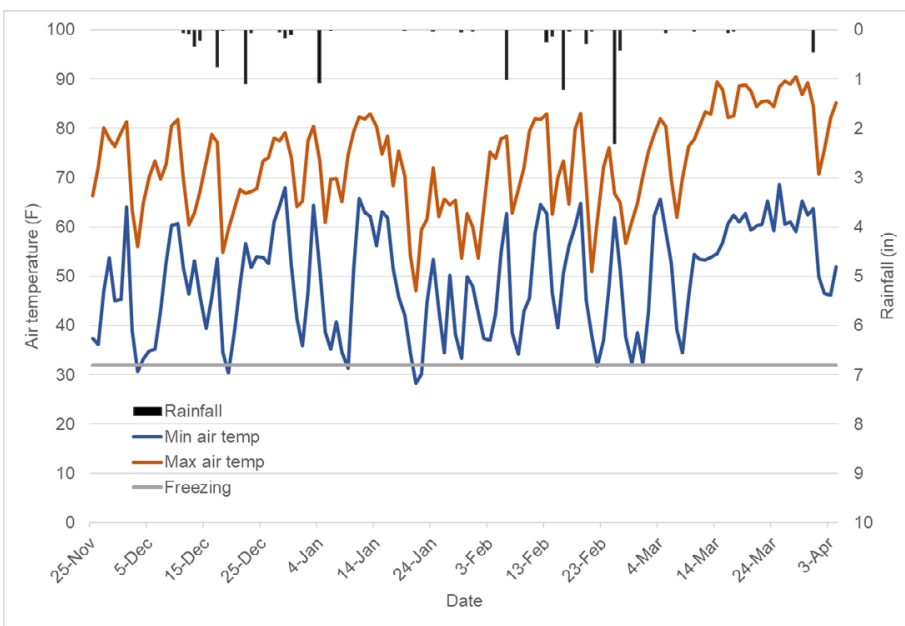

Figure 2. Rainfall (inches) and minimum and maximum air temperature ( ${ }^{\circ} \mathrm{F}$ ) for the 2019-2020 growing season in Live Oak, FL. Credits: Data retrieved from Florida Automated Weather Network (www.fawn.ifas.ufl.edu)

The previous crop on this land was peanut in summer and fall of 2019. The variability in barley growth seen in the plots can be attributed to the placement of discarded peanut vines after harvest. As peanuts are harvested, the vines are evacuated out of the back of the combine into windrows. The following barley crop was planted at an approximate angle of $45^{\circ}$ to the peanut vine windrow (Figures 5 and 6). Some of this variability was removed by the end of the crop cycle with applications of soluble fertilizer. The target fertilizer application rate for the 2019-2020 trial was 115 $\mathrm{lb} / \mathrm{acre} \mathrm{N}$. This rate was determined after a preliminary study with $90 \mathrm{lb} /$ acre of $\mathrm{N}$ showed reduced protein content in harvested grain and low test weight. There was a yield increase in 2019-2020 in comparison to the preliminary study in 2017-2018. Yield ranged from 11-69 bu/acre in 2017-2018, whereas in 2019-2020 yield ranged between $58-96 \mathrm{bu} / \mathrm{acre}$. The variability in yield resulting from frost damage and previous crop history led to no significant differences in yield between the varieties, even with large differences in mean yield and five replications.

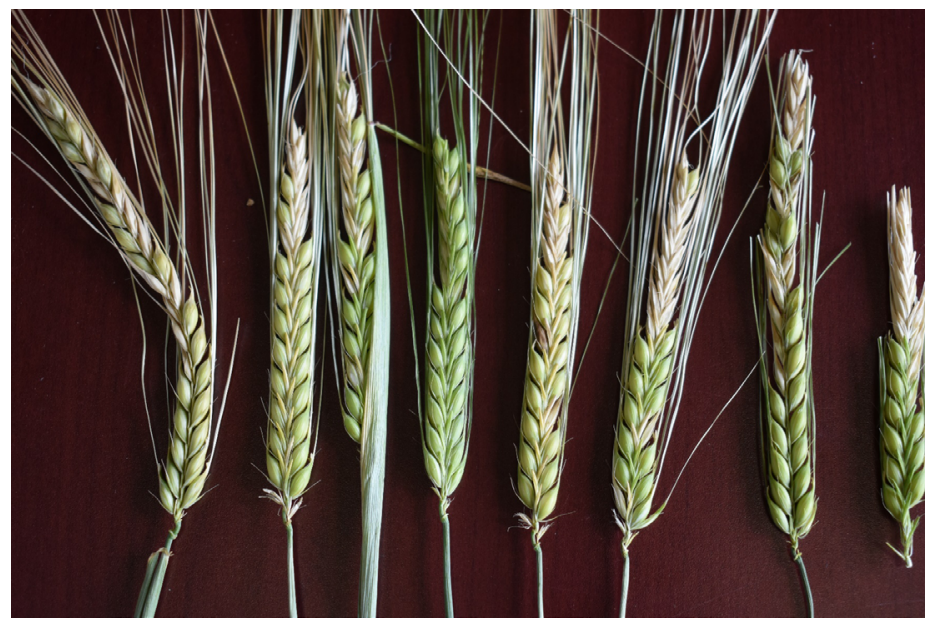

Figure 3. Barley heads with frost damage. Photograph taken 17 March 2020.

Credits: Charles Barrett, UF/IFAS

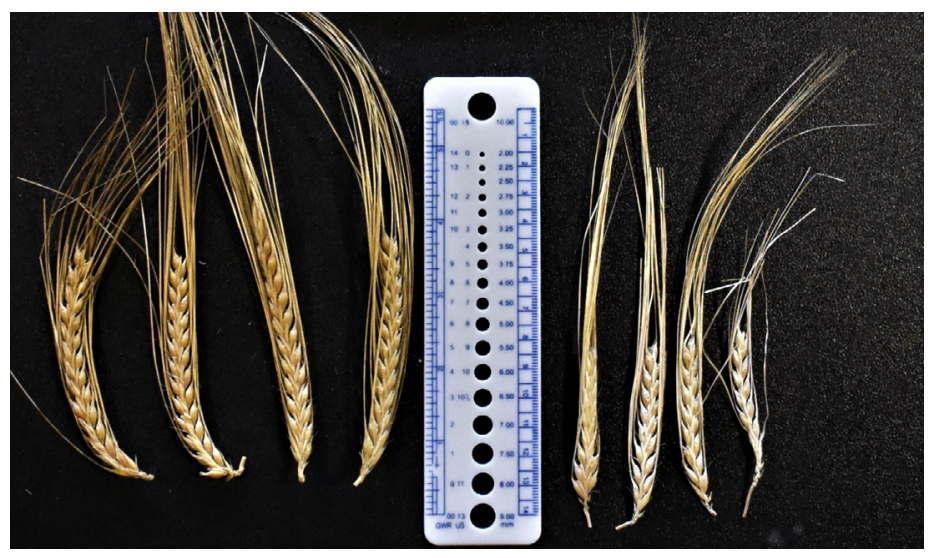

Figure 4. Mature barley seed heads left of ruler and frost-damaged, culled seed heads on right. Photograph taken 05 June 2020 while processing yield samples.

Credits: Charles Barrett, UF/IFAS

Another challenge to growing malting barley in north Florida is that corn and peanut are the predominant crops in the region. Corn is a host of pathogens that have a negative impact on barley. Peanut would be the preferred rotation crop for barley, but much of the peanut production in the region relies on the herbicide Cadre (BASF Corporation, Durham, NC), which requires an 18-month rotation interval. Peanut producers looking to rotate with barley 
will have to consider their weed-control options and the field history where barley will be planted. Peanut producers should also consider options to evenly spread the peanut vines when harvesting to ensure uniform barley growth.

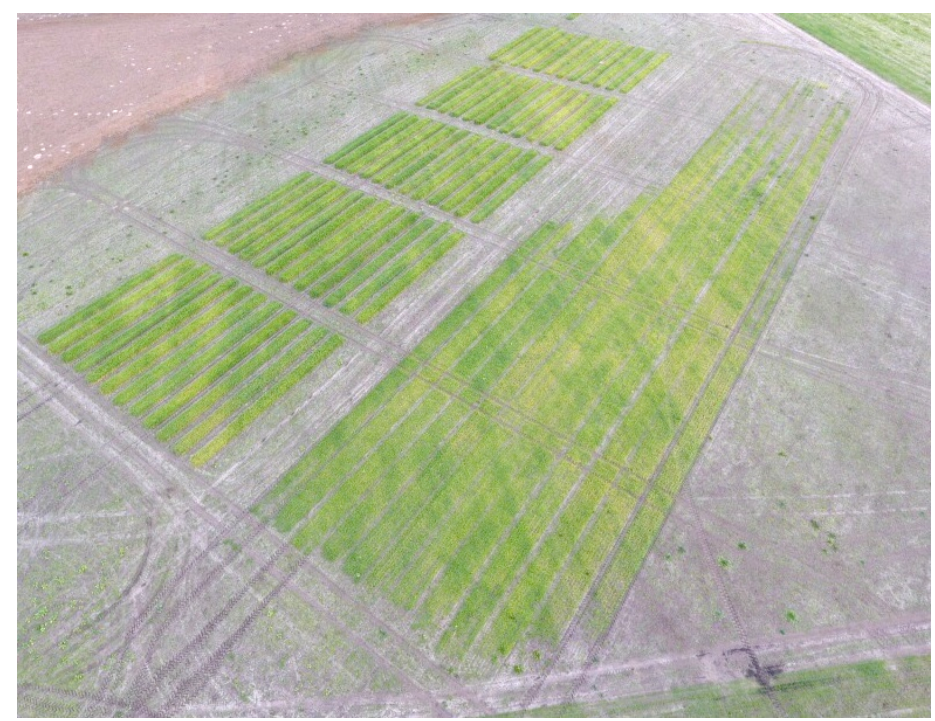

Figure 5. Aerial view of barley plots showing crop variability caused by previous crop of peanut planted at approximately $45^{\circ}$ to barley plots. Photograph taken 17 January 2020, Live Oak, FL.

Credits: Charles Barrett, UF/IFAS

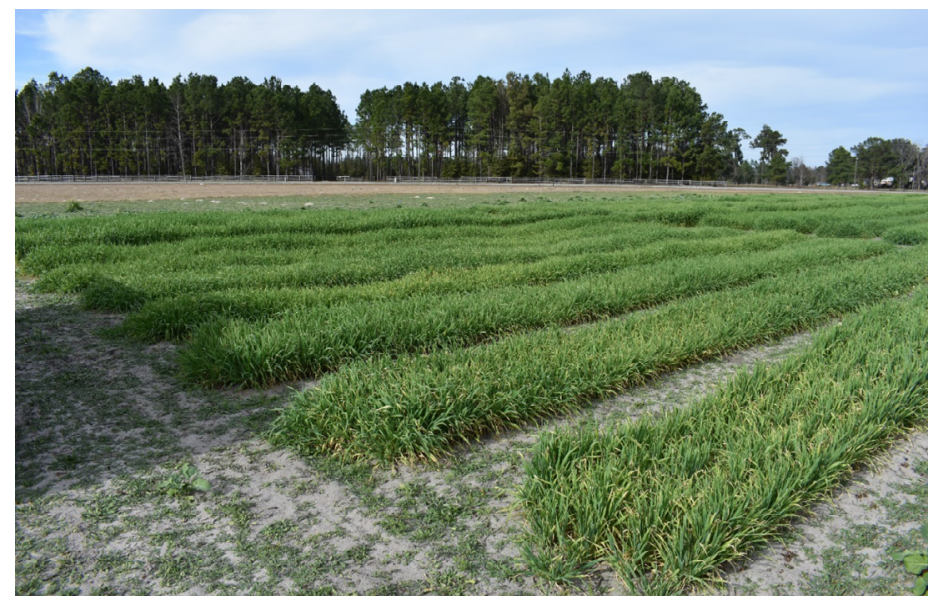

Figure 6. Plot view of crop variability (e.g., variation in plant height) caused by previous crop of peanut planted at approximately $45^{\circ}$ to barley plots. Photograph taken 4 February 2020, Live Oak, FL. Credits: Charles Barrett, UF/IFAS

\section{Final Remarks and Future Studies}

Although there are challenges to producing malting barley in north Florida, these results are encouraging and have led to a new grant award to support future research on malting barley production for Florida. The Support for Emerging Enterprise Development Integration Teams (SEEDIT) award from the UF/IFAS Dean for Research Office and Dean for Extension Office in partnership with the Senior Vice President for Agriculture and Natural Resources will provide financial support to continue the testing of barley varieties. The expected outcomes of this project are to identify 3-5 barley varieties for Florida that produce at levels that are potentially profitable and maintain desirable quality; determine the optimum planting date; identify potential markets and barriers to commercialization; and explore the feasibility, quality, and sensory properties of malted and unmalted barley. A separate but related SEEDIT project is researching the Florida brewery and distillery markets for locally grown barley and hops.

\section{References}

Brewer, T., and M. Long. 2020. “The Florida Breweries Report - November 2019.” https://brewerslaw.com/ the-florida-breweries-report-november-2019/

Brewers Association. 2019. "Florida Craft Beer Sales Statistics from 2018." Retrieved February 17, 2019. https://www.brewersassociation.org/statistics-and-data/ state-craft-beer-stats $/$ ?state $=$ FL

Taylor, T. G., G. F. Fairchild, A. W. Hodges, and T. J. Stevens. 2014. "Economic Contribution of the Florida Craft Brewing Industry to the Florida Economy." Sponsored project report. https://fred.ifas.ufl.edu/pdf/economicimpact-analysis/Craft_Brewing_FL_2014.pdf 
Table 1. Barley seed source, variety grown in trial, heading date, and days after planting that heading occurred.

\begin{tabular}{|l|c|c|c|}
\hline \multicolumn{1}{|c|}{ Source } & Variety Name & Heading Date 2020 & Days after Planting \\
\hline Johnny's Seeds & Pinnacle & 15 Feb & 83 \\
\hline \multirow{2}{*}{ Albert Lea Seed } & Conlon & 13 Feb & 81 \\
\cline { 2 - 4 } & ND Genesis & 17 Feb & 95 \\
\cline { 2 - 4 } & Tinka & 26 Feb & 78 \\
\hline Limagrain Cereal Seeds (LCS) & Robust (6-row) & 10 Feb & \\
\hline & Conlon & 13 Feb & \\
\hline NDSU & Genie & 29 Feb & 97 \\
\hline Meridian Seeds & Odyssey & 28 Feb & 96 \\
\hline
\end{tabular}

Table 2. Barley plant height, stem breakage resistance, and foliar disease ratings.

\begin{tabular}{|c|c|c|c|c|c|c|}
\hline \multirow{2}{*}{$\begin{array}{l}\text { Variety } \\
\text { Pinnacle }\end{array}$} & \multicolumn{2}{|c|}{$\begin{array}{l}\text { Plant Height }{ }^{\mathbf{2}} \\
\text { (in) }\end{array}$} & \multicolumn{2}{|c|}{$\begin{array}{c}\text { Stem Breakage } \\
(1-5)\end{array}$} & \multicolumn{2}{|c|}{$\begin{array}{l}\text { Foliar Diseasez } \\
\qquad(1-9)\end{array}$} \\
\hline & 27.5 & bc & 2.0 & $a b c$ & 2.8 & c \\
\hline Conlon (Johnny's) & 21.1 & de & 2.9 & c & 1.0 & $a$ \\
\hline ND Genesis & 29.6 & $\mathrm{~b}$ & 1.0 & $a b$ & 1.0 & a \\
\hline Tinka & 17.7 & ef & 1.0 & a & 1.2 & a \\
\hline Robust & 47.0 & a & 1.0 & a & 1.2 & $\mathrm{a}$ \\
\hline Conlon (Albert Lea) & 20.8 & de & 2.8 & bc & 1.0 & a \\
\hline Genie & 13.5 & $f$ & 1.0 & $\mathrm{a}$ & 1.4 & $\mathrm{a}$ \\
\hline Odyssey & 21.8 & cde & 1.8 & $a b c$ & 1.4 & $\mathrm{a}$ \\
\hline Opera & 20.2 & de & 3.1 & c & 1.6 & $\mathrm{a}$ \\
\hline Explorer & 21.8 & cde & 1.0 & a & 1.8 & $a b$ \\
\hline Esma & 21.2 & ed & 1.0 & $a$ & 2.6 & bc \\
\hline AAC Connect & 24.8 & bcd & 1.0 & a & 1.0 & $\mathrm{a}$ \\
\hline
\end{tabular}

${ }^{z}$ Values followed by the same letter within a column indicate means are not significantly different $(P \leq 0.05)$ with means separation by Tukey-Kramer test.

Table 3. Barley head counts, seed per head counts, yield and percentage of culled heads.

\begin{tabular}{|c|c|c|c|c|c|c|}
\hline \multirow{2}{*}{$\begin{array}{l}\text { Variety } \\
\text { Pinnacle }\end{array}$} & \multicolumn{2}{|c|}{ Head Count ${ }^{z}$} & \multicolumn{2}{|c|}{ Seed Count ${ }^{z}$} & \multirow{2}{*}{$\begin{array}{c}\text { Yield (bu/acre) } \\
77.9\end{array}$} & \multirow{2}{*}{$\begin{array}{c}\text { Culled Heads } \\
\text { (\% of Total) } \\
48\end{array}$} \\
\hline & 72.8 & $a b$ & 27.5 & $\mathrm{bc}$ & & \\
\hline Conlon (Johnny's) & 110.2 & a & 21.1 & de & 90.5 & 38 \\
\hline ND Genesis & 75.2 & $a b$ & 29.6 & $\mathrm{~b}$ & 86.5 & 33 \\
\hline Tinka & 89.6 & $a b$ & 17.7 & ef & 61.6 & 46 \\
\hline Robust & 35.6 & $\mathrm{~b}$ & 47.0 & $\mathrm{a}$ & 65.1 & 21 \\
\hline Conlon (Albert Lea) & 98.8 & a & 20.8 & de & 79.9 & 44 \\
\hline Genie & 110.4 & $\mathrm{a}$ & 13.5 & $f$ & 58.1 & 86 \\
\hline Odyssey & 113.4 & $\mathrm{a}$ & 21.8 & cde & 96.3 & 59 \\
\hline Opera & 84.2 & $a b$ & 20.2 & de & 66.2 & 72 \\
\hline Explorer & 97.6 & a & 21.8 & cde & 82.9 & 52 \\
\hline Esma & 105.4 & $a$ & 21.2 & de & 86.9 & 44 \\
\hline AAC Connect & 64.6 & $a b$ & 24.8 & bcd & 62.4 & 55 \\
\hline
\end{tabular}

